\title{
Separation of Powers and Universal Suffrage
}

\author{
By Danny Gittings \\ Associate Professor, College of Humanities and Law, School of Professional and \\ Continuing Education, University of Hong Kong. \\ PhD Candidate, Faculty of Law, University of Hong Kong
}

\begin{abstract}
The introduction of universal suffrage for the selection of the Hong Kong Chief Executive is often portrayed as the answer to the problems afflicting the executivelegislative relationship in Hong Kong. But even in the increasingly unlikely event that a consensus can be reached on the necessary electoral methods, the introduction of universal suffrage would, by itself, do little to address some of the structural problems that spring from the strong system of separation of powers-and, particularly, separation of persons - that exists under the Hong Kong Basic Law.
\end{abstract}

The near total separation of membership of the executive and legislature in Hong Kong weakens the political party system and creates the potential for deadlock between the two branches of the political structure. Such structural issues will need to be addressed alongside the introduction of universal suffrage.

If the introduction of a parliamentary system is considered too radical a solution in Hong Kong, such reforms should instead focus on finding the maximum cross membership possible within the present constitutional structure, and improving channels of communication between the executive and legislature. Such reforms would also offer hope for addressing some of the problems currently afflicting the executive-legislative relationship in Hong Kong, even if consensus cannot be reached on the introduction of universal suffrage.

\section{Introduction}

Separation of powers has long been a "controversial" and "politically charged" issue in Hong Kong. ${ }^{1}$ Hong Kong is quite possibly the only jurisdiction in the world where the local courts and representatives of the sovereign power that enacted its constitutional document are fundamentally at odds over whether or not such a system currently exists under the local constitutional framework. Ever since former leader Deng Xiaoping's 1987 warning against adopting a "separation of the three powers", 2 Chinese officials have repeatedly denied the existence of such a system under the Basic Law of the Hong Kong Special Administrative Region of the People's Republic of China (or "Hong Kong Basic Law").

\footnotetext{
${ }^{1}$ C.L. Lim and Johannes Chan, "Autonomy and Central-Local Relations" in Johannes Chan and C.L. Lim (eds.), Law of the Hong Kong Constitution (Hong Kong: Sweet \& Maxwell, 2011) at page 45.

${ }^{2}$ Deng Xiaoping, "Speech at a Meeting with the Members of the Committee for Drafting the Basic Law of the Hong Kong Special Administrative Region”, 16 April 1987 in Deng Xiaoping on the Question of Hong Kong (Beijing: Foreign Languages Press, 1993) at page 55.

${ }^{3}$ For a recent example, see Hao Tiechuan, "HK system not tripartite," China Daily (HK edition), 1 November 2013 at http://www.chinadaily.com.cn/hkedition/2013-11/01/content_17072822.htm (last accessed on 27 August 2014).
} 
By contrast, the Hong Kong courts have repeatedly held that the Hong Kong Basic Law "enshrines" the principle of separation of powers. ${ }^{4}$ Hong Kong's Chief Justice Geoffrey Ma recently repeated this point in a public lecture, explicitly stating that: "The prescribed constitutional model for Hong Kong involves the separation of powers". In Yau Kwong Man v Secretary for Security (2002), the Court of First Instance even struck down a statutory provision on the grounds that it infringed this fundamental principle that the court held enshrined in the Hong Kong Basic Law. ${ }^{6}$

Separation of powers can take many forms and, in holding that such a system is enshrined in the Hong Kong Basic Law, the courts have offered little guidance as to what form such separation takes in Hong Kong, beyond brief references to a tripartite division of powers between the executive, legislature and judiciary ${ }^{7}$ and highly debateable assertions this is based on "the Westminster model". Any more comprehensive definition of separation of powers needs to embrace several different elements. Vile (1998), ${ }^{9}$ author of what is often described as the "classic study" on the subject, ${ }^{10}$ suggests that a "pure" system of separation of powers includes the following four elements:

- Division of government into three separate branches: Executive, legislature and judiciary;

- Classification of all governmental functions as executive, legislative or judicial functions with each of these functions normally entrusted to the "proper" branch of government;

- Separation of persons: The three branches are composed of separate and distinct groups of people with no overlapping membership between them;

- Checks and balances between the three branches to avoid any one branch exercising arbitrary power. ${ }^{11}$

\footnotetext{
${ }^{4}$ Lau Cheong v HKSAR (2005) 5 HKCFAR 415, 447 (CFA). See also Lau Kwok Fai v Secretary for Justice (unrep., HCAL 177 and 180/2002, [2003] HKEC 711 at para. 19)(CFI) where separation of powers was described as a principle that "is woven into the fabric of the Basic Law".

${ }^{5}$ Geoffrey Ma Tao-li, "University Assembly - A Respect for Rights and a Respect for the Rights of Others", Speech at Lingnan University, 17 March 2014 at http://www.info.gov.hk/gia/general/201403/17/P201403170582.htm (last accessed on 27 August 2014). ${ }^{6}$ [2002] 3 HKC 457, 470 and 479 (CFI) holding that s67C of the Criminal Procedure Ordinance (Cap. 221) was invalid because it bestowed on the Chief Executive "the power to exercise what is an inherently judicial power" and so infringed Article 80 of the Hong Kong Basic Law.

${ }^{7}$ For example, Lau Cheong at 447. See also Lau Kwok Fai at para. 17, where Hartmann J. referred to "the principle that the primary functions of law making, law executing and law adjudicating are to be distinguished from each other".

${ }^{8}$ See Yau Kwong Man at 469 and Lau Kwok Fai at para. 18. The reference to the Westminster model (which emphasizes the role of Parliament in government) in the Hong Kong context has been criticised by Wesley-Smith [in "Judges and Judicial Power under the Hong Kong Basic Law" (2004) 34 HKLJ 83, 84] as "a misnomer here". See also Lo Pui Yin, The Judicial Construction of Hong Kong's Basic Law (Hong Kong: Hong Kong University Press, 2014) at page 36.

${ }^{9}$ M.J.C. Vile, Constitutionalism and the Separation of Powers (Indianapolis: Liberty Fund, 2nd edition, 1998).

${ }^{10}$ See, for example, Richard Bellamy, "The Political Form of the Constitution: the Separation of Powers, Rights and Representative Democracy" in Richard Bellamy (ed.), The Rule of Law and the Separation of Powers (Burlington: Dartmouth, 2005) at page 254.

${ }^{11}$ Vile, Constitutionalism and the Separation of Powers (see note 9) at pages 14-19.
} 
These divisions are rarely absolute and, in most jurisdictions practising a system of separation of powers, there is usually some limited overlap between the executive, legislature and judiciary. That is particularly true of checks and balances which, at least in the sense in which the term is generally understood today, involve breaking down the barriers between the three branches of government to the extent necessary to provide some check or balance on any one branch abusing its powers. ${ }^{12}$ To take just one example, the executive's power to veto bills passed by the legislature inevitably involves limited inroads by the executive into the legislative process.

The same is true of separation of persons, another area where there is often some overlap, at least between the membership of the executive and legislature. That is certainly true under a parliamentary system of government, such as in the United Kingdom, where the membership of the upper echelons of the executive is-by definition-drawn from the ranks of the legislature. So to deny the existence of any overlapping membership is to deny the existence of any form of separation of powers in any country with a parliamentary system of government, a view which-although it enjoyed some academic support in the past ${ }^{13}$ - has now been firmly rejected by the English courts. ${ }^{14}$

In the absence of a requirement for total separation, it is the degree of separation between executive, legislature and judiciary which distinguishes different systems of separation of powers. Although even in a parliamentary system the majority of members of the legislature remain outside the ranks of the executive, ${ }^{15}$ the degree of overlap which does exist is often credited with averting perennial deadlock between the executive and legislature. And it is the absence of such overlapping membership under the Hong Kong system which merits particularly close attention, in considering the likely impact of universal suffrage and other possible reforms to Hong Kong's political system.

\footnotetext{
${ }^{12}$ Ibid. at pages 19-20. This is sometimes also described as an amalgam of the doctrine of separation of powers with the theory of checks and balances.

${ }^{13}$ See, for example, O. Hood Phillips, "A Constitutional Myth: Separation of Powers" (1977) 93 Law Quarterly Review 11, 11.

${ }^{14}$ See, in particular, Lord Diplock's statement that “it cannot be too strongly emphasised that the British constitution, though largely unwritten, is firmly based on the separation of powers" in Dupont Steels Ltd. v Sirs [1980] 1 All ER 529, 541.

${ }^{15}$ In the UK for instance, Section 2 of the House of Commons Disqualification Act 1975 limits to a maximum of 95 the number of members of the House of Commons who are allowed also to be government ministers.
} 


\section{Separation of Powers under the Hong Kong Basic Law}

Perhaps due to political sensitivities, there is no explicit reference to separation of powers in the Hong Kong Basic Law. Its drafters did use the term during the early stages of the drafting process. Davis (1989) notes that drafters initially came out strongly in favour of "a somewhat American style of separation of powers with checks and balances". ${ }^{16}$ In its first progress report in late 1986, the Political Structure Sub-group of the Basic Law Drafting Committee clearly stated that: "The Group considers that, under the principle of 'one country two systems', in principle the political structure of HKSAR will adopt the model of 'separation of powers'."17

That changed after a speech by Deng Xiaoping to Basic Law drafters a few months later. China has long harboured strong ideological objections to the whole concept of separation of powers, which classical Marxist theory rejects as a "constitutional fallacy" that ignores the class nature of society. ${ }^{18}$ The constitutional principle of governance in China is instead one of "democratic centralism" "19 and Chan (2007) describes the rejection of separation of powers as a "major characteristic of the Chinese legal system". ${ }^{20}$

Whatever the motivation for his April 1987 warning against adopting a "separation of the three powers" in Hong Kong, ${ }^{21}$ Deng's speech to Basic Law drafters put an end to any further explicit references to separation of powersalthough not checks and balances, a term which continued to be used by mainland drafters. ${ }^{22}$ One drafter and senior mainland official was quoted shortly afterwards as stating, "we should not talk about separation of the three powers any more to avoid misunderstanding". ${ }^{23}$ Hao (2013) notes that "the term was never mentioned again in official deliberations of the drafting process or the Basic Law itself". ${ }^{24}$

Instead the term "executive-led government", which particularly emphasises the powers of the Chief Executive, subsequently began to be promoted as China's preferred alternative description of Hong Kong's constitutional structure, although only after the drafting of the Hong Kong Basic Law had been completed. ${ }^{25}$ In principle, a system of executive-led government is not necessarily incompatible with

\footnotetext{
${ }^{16}$ Michael C. Davis, Constitutional Confrontation in Hong Kong (Basingstoke: Macmillan, 1989) at page 31 .

${ }^{17}$ Progress Report of the Sub-Group on Political Structure (8 November 1986).

${ }^{18}$ Hal Draper, Karl Marx's Theory of Revolution (New York: Monthly Review Press, 1977) at page 316.

${ }^{19}$ Articles 2 and 3 of the Constitution of the People's Republic of China 1982.

${ }^{20}$ Johannes Chan, "Basic Law and Constitutional Review" (2007) 37 HKLJ 407, 408.

${ }^{21}$ Perhaps because they contradicted the stance of the drafters, Deng's remarks on separation of powers were so sensitive that they were initially omitted from the officially published text of his speech to Basic Law drafters, although they were subsequently published in full. See Yau Shing Mu, "Deng's words prompt new look by drafters", Hong Kong Standard, 18 April 1987 and.Deng, "Speech at a Meeting with the Members of the Committee for Drafting the Basic Law (see note 2) at page 55.

${ }^{22}$ See, for example, Xiao Weiyun, One Country, Two Systems: An Account of the Drafting of the Hong Kong Basic Law (Beijing: Peking University Press, English edition, 2001) at page 245.

${ }^{23} \mathrm{Li}$ Hou, deputy director of the State Council's Hong Kong and Macau Affairs Office,cited in Chris Yeung, "Change of view by top official", South China Morning Post, 9 June 1987.

${ }^{24}$ Hao, "HK system not tripartite," (see note 3). This English translation uses the term "tripartite political system" rather than "separation of the three powers".

${ }^{25}$ The origins of this term appear to date back to the mid-1990s. See further Lo, The Judicial Construction of Hong Kong's Basic Law (see note 8) at pages 40-46.
} 
one of separation of powers, and that point is sometimes made by mainland scholars. ${ }^{26}$ But it appears Chinese officials remain concerned that, even if dominance by the executive is accepted, acceptance of any form of separation of powers would still risk undermining its control over developments in Hong Kong through the Chief Executive who, in contrast to the legislature and the judiciary, is directly accountable to Chinese Central Authorities. ${ }^{27}$ Hao (2013) warns that a system of separation of powers, "would mean that instructions from the central government can be challenged by LegCo and/or the High Court". ${ }^{28}$

However, as Ghai (1999) notes: "The doctrine of the separation of powers can accommodate many configurations of the relationship among state institutions."29 According to Lutz (2006), who has sought to measure such separation through a Separation of Powers Index, almost all political systems use separated powers to some extent, ${ }^{30}$ although the extent of such separation varies greatly, along what he describes as a "separation of powers continuum". 31

Given this broad ambit of the doctrine, it is difficult to deny that the arrangements under the Hong Kong Basic Law fall somewhere within the "many configurations",32 that come within the scope of separation of powers. That is certainly the stance taken by the Hong Kong courts, ${ }^{33}$ and also by many scholars in Hong Kong. Wesley-Smith was one of the first to make this point, writing in 1990 that, "the structure of the Basic Law and its allocation of functions to the Legislative Council, the Chief Executive and the courts is very similar to the structure of other constitutions said to exhibit the separation of powers". ${ }^{34}$ More than a decade later, he put the point more strongly, writing in 2005 that "it seems impossible to argue that the Basic Law does not clearly establish three separate branches of government each with specified powers in accordance with the separation doctrine". ${ }^{35}$

That conclusion is based primarily on the separate sections in Chapter IV of the Hong Kong Basic Law on Political Structure, which allocate separate and distinct powers to the three branches that constitute an integral feature of the conventional

\footnotetext{
${ }^{26}$ See, for example, Chen Xinxin, "A Study on Hong Kong's Executive-led System” in One Country Two Systems Research Institute, Seminar on Review and Prospect of the Basic Law: Collection of Articles 2007 (Hong Kong, 2010) at page 281. See also Lo, The Judicial Construction of Hong Kong's Basic Law (see note 8) at pages 47-48.

${ }^{27}$ See, for example, the comments of Chen Zuoer, Deputy Director of the Hong Kong and Macao Affairs Office of the State Council, at a seminar in Beijing on 12 March 2004. Cited by Albert H.Y. Chen in "Executive-led Government, Strong and Weak Governments and Consensus Democracy" in Chan and Harris (eds.) Hong Kong's Constitutional Debates (Hong Kong Law Journal Limited, 2005) at page 10 .

${ }^{28}$ Hao, "HK system not tripartite" (see note 24).

${ }^{29}$ Yash Ghai, Hong Kong's New Constitutional Order: The Resumption of Chinese Sovereignty and the Basic Law (Hong Kong: Hong Kong University Press, 2nd edition, 1999) at page 263.

${ }^{30}$ Donald S. Lutz, Principles of Constitutional Design (New York: Cambridge University Press, 2006) at page 109 .

${ }^{31}$ Ibid. at page 123 .

${ }^{32}$ Ghai (1999). See note 29.

${ }^{33}$ See note 4 earlier.

${ }^{34}$ Peter Wesley-Smith, "The Separation of Powers" in Wesley-Smith (ed.) Hong Kong's Basic Law: Problems and Prospects (Hong Kong: Faculty of Law, University of Hong Kong, 1990) at page 72.

${ }^{35}$ Peter Wesley-Smith, "The Hong Kong Constitutional System: The Separation of Powers, ExecutiveLed Government and Political Accountability" in Chan and Harris (eds.), Hong Kong's Constitutional Debates (see note 27) at pages 3-4.
} 
tripartite system of separation of powers. The executive, led by the Chief Executive, is assigned a long list of powers under the Hong Kong Basic Law, ${ }^{36}$ including responsibility for the implementation of laws. ${ }^{37}$ But the Hong Kong Basic Law places responsibility for law-making in the hands of the legislature, as part of another long list of powers assigned to Legco. ${ }^{38}$ There is less detail on the power of the courts. But the Hong Kong Basic Law does assign to the courts responsibility for "exercising the judicial power of the [Hong Kong Special Administrative] Region". 39

Checks and balances are also present in abundance throughout the Hong Kong Basic Law. While only the legislature can enact primary legislation, the Chief Executive has the power to veto any bills passed by the legislature, ${ }^{40}$ a power similar to that exercised by the leaders of the executive branch in most countries with a presidential system of government, such as the US. As in the US, the Chief Executive's veto of a bill passed by the legislature may be overridden by a two-thirds majority of legislators, although the Hong Kong Basic Law's provisions on this are more complex than those in the US Constitution, since it gives the Chief Executive the alternative of instead dissolving the legislature and calling fresh elections. ${ }^{41}$

As a result, many scholars characterise the system of separation of powers that exists under the Hong Kong Basic Law as one which, in the words of Ghai (1999), "owes more to the presidential system than the parliamentary system". ${ }^{42}$ More specifically, the system under the Hong Kong Basic Law is often characterised as one which bears a strong resemblance to the separation of powers practised under the US Constitution. For instance, Wesley-Smith (1990) notes that: "In some respects the model for the SAR's political system seems to have been found in the USA". "Shiu (2010), who served as Deputy Secretary General of the Basic Law Consultative Committee suggests that, "the internal operation of Hong Kong's political system is quite similar to the American executive-legislative relations". ${ }^{4}$

That resemblance is particularly striking in the area of separation of persons where, as in the US, the Hong Kong system inclines in the direction of near total separation of persons between the executive and legislature. Even if a legislator is

\footnotetext{
${ }^{36}$ Articles 48 and 62.

${ }^{37}$ Article 48(2).

${ }^{38}$ See Article 73 and, especially, Article 73(1).

${ }^{39}$ Article 80.

${ }^{40}$ Under Article 76, any bill passed by Legco "may take effect only after it is signed and promulgated by the Chief Executive". Under Article 49, instead of signing and promulgating a bill, the Chief Executive may instead return to Legco "for reconsideration" any bill which the Chief Executive considers "not compatible with the overall interests of the Region".

${ }^{41}$ Under Articles 49 and 50, if Legco passes by a two-thirds majority any bill returned for reconsideration, the Chief Executive must either sign and promulgate it or dissolve Legco and call fresh elections. However dissolving Legco is an extremely risky path unlikely to appeal to many Chief Executives since, under Article 52(2), he will then be forced to resign if the new Legco again passes the bill by a two-thirds majority and he still refuses to sign it.

${ }^{42}$ Ghai, Hong Kong's New Constitutional Order (see note 29) at page 263. For further characterisations of the Hong Kong system as a presidential system, see also Ma Ngok, "Executive-Legislative Relations: Assessing Legislative Influence in an Executive-Dominant System," in Lau Siu-Kai (ed.) The First Tung Chee-hwa Administration: The First Five Years of the Hong Kong Special Administrative Region (Hong Kong: The Chinese University Press, 2002) at pages 353 and 368.

${ }^{43}$ Wesley-Smith, "The Separation of Powers" (see note 34) at page 72.

${ }^{44}$ Shiu Sin-por, "Executive-Legislative Relations Under the Basic Law" in Seminar on Review and Prospect of the Basic Law: Collection of Articles 2007 (Hong Kong: One Country Two Systems Research Institute, 2010) at page 272.
} 
appointed to a position within the executive, as has happened on a number of occasions in recent years, the practice so far has always been for that legislator to resign both their membership of Legco and also any political party membership. So the only area of overlapping membership is the very small number of legislators appointed by the Chief Executive to sit on the Executive Council.

This near total separation of persons between the executive and legislature has been identified by many writers as one of the contributing factors to the persistent discord and even "dysfunctional" 45 relationship between the executive and legislature that has been such a persistent feature of Hong Kong's post-1 July 1997 history. According to mainland drafters of the Hong Kong Basic Law, coordination between the executive and legislature was meant to be as important as the system of checks and balances, with Xiao (2001) describing them as "two sides of the same coin". 46 However in a Constitutional Development Task Force report in 2004, the HKSAR Government described the separate membership of the executive and legislature as posing severe obstacles to such coordination:

"[I]n reality, the executive authorities and the legislature are respectively taken up by people of different backgrounds and perspectives; the executive authorities and the legislature often are able to "regulate" (i.e. to act as a mutual check) but are not able to "co-ordinate" (i.e. to fully complement) each other. Furthermore, under the present system, the Chief Executive does not have established support in the Legislative Council. This has had an adverse effect on the executive-led system and administrative efficiency." 47

Writing in $2006 \mathrm{Ip}$, who had served as a senior member of the executive and would subsequently become a legislator, ${ }^{48}$ suggested that "it has now become clear with hindsight, as the Basic Law drafters of the 1980s lacked in-depth understanding of the theory and practice of representative government, they basically cobbled together a constitutional system based on existing practice, and incorporated features borrowed from western systems of representative government". ${ }^{49}$

\footnotetext{
${ }^{45}$ Ian Scott, "The Disarticulation of Hong Kong's Post-Handover Political System" (2000) 43 The China Journal 29, 29.

${ }^{46}$ Xiao, One Country, Two Systems: An Account of the Drafting of the Hong Kong Basic Law (see note 22) at page 254 .

${ }^{47}$ HKSAR Government, The Second Report of the Constitutional Development Task Force : Issues of Principle in the Basic Law Relating to Constitutional Development (April 2004), at http://www.legco.gov.hk/yr03-04/english/panels/ca/papers/ca0416cb2-report2-e.pdf (last accessed on 10 Sept 2014).

${ }^{48}$ Ip was Secretary for Security, a principal official position in the Hong Kong SAR Government, from 1998-2003. Since 2008, she has been a member of the Legislative Council and, since 2012, also a member of the Executive Council.

${ }^{49}$ Regina Ip, Hong Kong: A Case Study in Democratic Development in Transitional Societies (Stanford University: MA thesis, 2006) at page 36.
} 


\section{Universal Suffrage and Other Possible Reforms}

The introduction of universal suffrage, especially for the selection of the Chief Executive, is often portrayed as the answer to the problems afflicting the executivelegislative relationship in Hong Kong. Take, for example, this commentary which appeared in the state-run China Daily, unequivocally asserting that: "There can be no argument that successful implementation of universal suffrage will give the city's next top leader a stronger mandate that will enable him or her to implement policies more effectively. ${ }^{, 50}$ Citing work by several authors including Ip (2006) ${ }^{51}$ and Ma (2007), ${ }^{52}$ Chen (2007) noted that: "Most scholars consider that full democratization is the way out of the predicament of governance in the HKSAR". ${ }^{3}$

It is not the intention of this paper to dispute the benefits that selecting Hong Kong's Chief Executive through universal suffrage could bring, particularly in enhancing the Chief Executive's legitimacy to rule in the eyes of the Hong Kong public. Nonetheless there is a danger that too heavy a focus on the issue of universal suffrage risks obscuring other issues that currently impact on the state of governance in Hong Kong. Salkeld (2014), a senior civil servant in the HKSAR Government, notes that: "Today we see the relationship between the Chief Executive and the legislature through the distorting lens of the unfinished business over electoral arrangements. $"{ }^{54}$ He points out that, even in the event that agreement could be reached on the introduction of universal suffrage for the election of the Chief Executive and all seats in the legislature, "the American style constitutional divorce between Chief Executive and the legislature will remain since it is embedded in the Basic Law". 55

In particular, it would be a mistake to see the introduction of universal suffrage as the solution to the currently dysfunctional relationship between the executive and legislature, unless accompanied by other reforms to address the structural issues associated with the near total separation of the personnel of these two branches of government. Given the diminishing prospects for securing the two-thirds majority in Legco necessary for changing the system of selecting the Chief Executive, ${ }^{56}$ these are reforms which could also be usefully pursued even in the absence of the introduction of universal suffrage.

Experience overseas suggests that universal suffrage may not necessarily lead to a well-functioning relationship between the executive and legislature, particularly where the membership of the two branches is rigidly separated from one another. That is certainly the belief of a substantial body of prominent academic critics of the

\footnotetext{
50 "Let Political Wisdom Prevail," China Daily, 3 June 2015.

${ }^{51}$ Ip (see note 49).

${ }^{52}$ Ma Ngok, Political Development in Hong Kong: State, Political Society and Civil Society (Hong Kong: Hong Kong University Press, 2007).

${ }^{53}$ Albert HY Chen, "The Basic Law and the Development of the Political System in Hong Kong" (2007) 15 (1) APLR 19, 29.

${ }^{54}$ Salkeld has served as head of the HKSAR Government's Efficiency Unit since 2009. See Kim Salkeld, "Should Hong Kong Public Services Change? Can They?", Public Policy Forum at the Faculty of Social Sciences of the University of Hong Kong, 3 December 2014. Available at http://www.socsc.hku.hk/pppl/ksalk/video.html (last accessed on 19 January 2015).

55 Ibid.

${ }^{56}$ As required under Annex I(7) of the Hong Kong Basic Law.
} 
near total separation of the membership of the executive and legislature in the US. Such criticisms were famously highlighted in 2005 when the widely-watched American TV political drama The West Wing cited a fictional US Presidential advisor as suggesting that "[h]alf the Faculty at Yale law" blame American-style separation of powers "for wreaking havoc on over 30 countries around the globe". Professor Bruce Ackerman's influential Harvard Law Review article in 2000 titled "The New Separation of Powers", 58 in which he paraphrased fellow Yale Professor Juan José Linz as describing such separation of powers as "one of America's most dangerous exports". 59

Linz (1994) had warned of the "nightmare scenario" of constitutional collapse, in which continual conflicts between a rigidly separated executive and legislature ultimately encourage one side to resolve the deadlock by dismantling the constitutional structure. ${ }^{60}$ However, of more direct relevance in the Hong Kong context would be Ackerman's (2000) alternative scenario of such continual conflicts instead resulting in prolonged deadlock:

"Rather than all out war, president and house may merely indulge a taste for endless backbiting, mutual recrimination, and partisan deadlock. Worse yet, the contending powers may use the constitutional tools at their disposal to make life miserable for each other: the house will harass the executive, and the president will engage in unilateral action whenever he can get away with it. I call this scenario the 'crisis in governability'.",61

Substitute the words "Chief Executive" for "president" and "Legislative Council" for "house" and many might see in this an accurate description of the "crisis in governability" that currently exists in Hong Kong. That might, in turn, suggest that the solution lies in a total overhaul of the constitutional structure in the Hong Kong Basic Law to replace the present separation of the membership of the executive and legislature with something closer to a parliamentary system

That is the solution advocated in the American context by Ackerman (2000) and other critics of the US presidential system, who favour abandoning it in favour of a system of "constrained parliamentarianism" in which checks and balances would be preserved through other means. ${ }^{62}$ Also writing about the system in the US, Wilson (1996) notes that: "If one makes a list of the most frequently proposed alterations to

\footnotetext{
57 “The Wake Up Call” (The West Wing, Season 6, Episode 14, aired on 9 February 2005). Available at https://www.youtube.com/watch?v=gLoio0Z6jLw (last accessed on 29 August 2014).

${ }^{58}$ Bruce Ackerman, "The New Separation of Powers" (2000) 113 Harv. L. Rev. 633-729.

${ }^{59}$ Ibid. at pages 644-645.

${ }^{60}$ Juan J. Linz, "Presidential or Parliamentary Democracy: Does It Make a Difference?" in Juan J. Linz and Arturo Valenzuela, The Failure of Presidential Democracy (Baltimore: Johns Hopkins University Press, 1994) at pages 3-90. See, however, the rebuttal by Matthew S. Shugart, and John Carey, [in Presidents and Assemblies: Constitutional Design and Electoral Dynamics (Cambridge: Cambridge University Press, 1992) at page 42] who found "no justification for the claim of Linz and others that presidentialism is inherently prone to crises that lead to breakdown".

${ }^{61}$ Ackerman "The New Separation of Powers" (see note 58) at page 646.

${ }^{62}$ Ibid. at page 727 .
} 
our constitutional arrangements, the odds are high that these proposals will call for a reduction in the separation of powers". 63

Similar structural reforms have sometimes been advocated in Hong Kong. According to Ip (2006): "As the parliamentary system provides greater assurance of an executive-led government, the Basic Law should be amended to provide for the implementation of the equivalent of a parliamentary system". ${ }^{64}$ Civic Party lawmaker Alan Leong advocated the introduction of a parliamentary system during his unsuccessful candidacy for Chief Executive in $2007 .^{65}$

However the option of moving to a parliamentary system was rejected during the drafting of the Hong Kong Basic Law. ${ }^{66}$ It is perhaps just conceivable that experience of the prolonged constitutional deadlock under the current rigid separation of membership of the executive and legislature might eventually prompt mainland scholars and officials to reconsider the merits of a parliamentary system as an alternative to the present deadlock. Noted political sociologist Larry Diamond recently sought to encourage precisely such a rethink: "If Beijing is worried about unfettered populism and polarisation, switching to a parliamentary system would provide a better and safer model". ${ }^{67}$

But there is no sign of such a rethink as yet and, given the strong presence of the pan-democracy camp in Legco, the central authorities could be expected to be intensely suspicious of any move towards a system that might increase the power that members of the legislature wield over the executive. In any case, given the extensive amendments to the Hong Kong Basic Law that would be necessary to introduce a parliamentary system, such a reform could only be regarded as a long-term goal at best.

Allowing the Chief Executive to be a member of a political party is sometimes suggested as a more immediate step that could accompany the introduction of universal suffrage and help bridge the disconnect between the executive and legislature. Several local political party leaders have been frequently mentioned as potential candidates for Chief Executive in 2017 and beyond. ${ }^{68}$ It is sometimes suggested that allowing such politicians to retain their party membership, were they successfully elected, would make it easier for them to secure support for government

\footnotetext{
${ }^{63}$ James Q. Wilson, "Does the separation of powers still work?” in Joshua Cohen and Archon Fung (eds.), Constitution, Democracy and State Power: The Institutions of Justice: Volume 1 Constitutional Government (Cheltenham: Edward Elgar, 1996) at page 37.

${ }^{64}$ Ip, Hong Kong: A Case Study in Democratic Development in Transitional Societies (see note 49) at page 62.

${ }^{65}$ Chen, "The Basic Law and the Development of the Political System in Hong Kong" (see note 53) at page 37.

${ }^{66}$ Xiao, One Country, Two Systems: An Account of the Drafting of the Hong Kong Basic Law (see note 22) at page 247.

${ }^{67}$ Jeffie Lam, "Leading democracy scholar Larry Diamond suggests forming parliament in Hong Kong", South China Morning Post, 10 March 2014.

${ }^{68}$ Notably Regina Ip, leader of the New People's Party, who tried to stand in the 2012 contest, and Alan Leong, leader of the Civic Party, who unsuccessfully stood in the 2007 contest.
} 
policies from party colleagues in the legislature ${ }^{69}$ Former Chief Executive Tung Chee hwa has recently appeared to endorse this view. ${ }^{70}$

At present, although candidates can retain their party membership while standing for election, the Chief Executive Election Ordinance (Cap. 569) requires anyone successfully elected as Chief Executive to relinquish any political party membership and promise not to join any party for the duration of their term of office. ${ }^{71}$ Since this prohibition is only written into Hong Kong legislation, in theory it should be easier to change than other structural reforms requiring amendments to the Hong Kong Basic Law. However China might well question whether permitting political party membership would be consistent with the Chief Executive's obligation of accountability to the Central People's Government. ${ }^{72}$ Nor does such a reform seem on the agenda at present, with the Hong Kong SAR Government noting that the issue attracted relatively little discussion during its first-stage public consultation exercise on possible reforms to the electoral system for 2016-2017. ${ }^{73}$

In any case, there is reason to question how big a difference allowing the Chief Executive to be a member of a political party would necessarily make to the executive-legislative relationship. First of all, under the current electoral system it is extremely unlikely that any one political party could ever command a majority of seats in Legco. That means any Chief Executive who retained their political party membership could, at best, count on the support of a minority of party colleagues within the legislature

Even this is open to question. Experience overseas suggests that where there is a rigid separation of the membership of the executive and legislature, the political interests of party members in the legislature frequently differ fundamentally from those of the head of the executive, even where they come from the same political party. Samuels and Shugart (2010), authors of the most sustained research in this area, put the point as follows: "[S]eparate election of the executive and legislative branches of government enhances the incentives for politicians in different branches of the same party to go their own way. ... This mutually assured survival in office means that neither 'branch' of a single party is bound to support the other as in a parliamentary

\footnotetext{
${ }^{69}$ See, for example, Ip, Hong Kong: A Case Study in Democratic Development in Transitional Societies (see note 49) at page 61. See also Simon N.M. Young and Richard Cullen, Electing Hong Kong's Chief Executive (Hong Kong: Hong Kong University Press, 2010) at pages 101-102.

70 "Party affiliation would help Chief Executive", South China Morning Post, 8 September 2014.

${ }^{71}$ See Section 31, which requires that within seven days of being elected the successful candidate (a) publicly make a statutory declaration to the effect that he is not a member of any political party; and (b) lodge with the Returning Officer a written undertaking to the effect that he will not, if appointed as the Chief Executive- (i) become a member of any political party; or (ii) do any act that has the effect of subjecting himself to the discipline of any political party, during his term of office as the Chief Executive.

${ }^{72}$ Under Article 43(2) of the Hong Kong Basic Law.

${ }^{73}$ Hong Kong SAR Government, Report on the Public Consultation on the Methods for Selecting the Chief Executive in 2017 and for Forming the Legislative Council in 2016 (July 2014), para. 3.63 at http://www.2017.gov.hk/filemanager/template/en/doc/report/consultation_report.pdf (last accessed 4 Sept. 2014).
} 
system. In this way, the constitutional separation of powers provides a recipe for intraparty conflict.",74

Samuels and Shugart's (2010) rather gloomy conclusion is that responsible party government simply "cannot exist under the separation of powers". Instead, "irresponsible parties are the likely result" of any system of separation of origin and survival as far as members of the executive and legislature are concerned. ${ }^{75}$

That brings us back to the structural problems posed by total separation of the membership of the executive from the legislature, particularly in terms of the resulting difference in political self-interest of the members of these two bodies. Even if the wholesale introduction of a parliamentary system has to be considered impractical, at least in the short-term, that need not necessarily preclude the introduction of some elements associated with such a system - with the goal of trying to reduce the extent of the separation between the two branches of the political structure. Foreseeing the problems that Chief Executives would experience in trying to govern Hong Kong under a system which separated membership of the legislature from the executive, Ghai (1999) predicted that "the executive may consequently be forced into operating the political system in less of a presidential and more of a parliamentary style". ${ }^{76} \mathrm{He}$ suggested this might involve either appointing legislators to Exco, specifically those from the biggest political parties or coalition of parties, or bringing legislators directly into the heart of the executive by appointing them as principal officials. ${ }^{77}$

Taking Ghai's second option first, nominating legislators to top governmental posts ${ }^{78}$ might go some way towards addressing the structural problem highlighted by Samuels and Shugart of separation of survival of members of the executive and legislature under a presidential-like system. Although formally speaking, such legislators would still be elected separately from the executive, in practical terms their political fortunes would then become closely entwined with those of the executive. Such an option might prove particularly attractive for a Chief Executive elected by universal suffrage, providing not only a loyal core of supporters in Legco but also a means of deflecting criticism of heading an administration of unelected appointees. That rationale might become even stronger if a Chief Executive was facing accusations of having been elected through a system of "fake" universal suffrage, providing an opportunity for a Chief Executive to burnish their democratic credentials by surrounding themselves with a layer of elected officials.

Appointing members of Legco to principal official posts could also be seen as an evolutionary rather than revolutionary reform, given the long track record of appointing legislators to such posts ${ }^{79}$ - with the crucial difference being that, until

\footnotetext{
${ }^{74}$ David J. Samuels and Matthew S. Shugart, Presidents, Parties, and Prime Ministers: How the Separation of Powers Affects Party Organization and Behavior ((New York: Cambridge University Press) at page 9.

${ }^{75}$ Ibid. at page 252. See also page 24 for more on the definition of "responsible" parties.

${ }^{76}$ Ghai, Hong Kong's New Constitutional Order (see note 29) at page 294.

${ }^{77}$ Ibid. at pages 294-295.

${ }^{78}$ Under Article 48(5) of the Hong Kong Basic Law, it is the Central People's Government (CPG) which appoints principal officials of the HKSAR Government, and the Chief Executive's power is limited to nominating and reporting them to the CPG for appointment.

${ }^{79}$ See, for example, the appointment of then legislator Henry Tang as Secretary for Commerce, Industry and Technology in 2002 and, more recently, the appointment of then legislator Paul Chan as Secretary for Development in 2012.
} 
now, such appointees have always been expected to resign as legislators upon being appointed. However there would be practical obstacles to such a reform. Some principal official positions should not be filled by legislators, especially those related to law enforcement and auditing, to avoid politicising such activities. ${ }^{80}$ Similar arguments might also be advanced in respect of the positions of Secretary for the Civil Service and Secretary for Justice. ${ }^{81}$

A more fundamental objection is the provision in Article 79(4) of the Hong Kong Basic Law barring any legislator from remaining as a member of the council: "When he or she accepts a government appointment and becomes a public servant" (emphasis added). It seems clear from the wording of this provision that taking up a government post does not, in itself, disqualify a legislator from remaining in Legco-with the crucial issue being whether or not they are classified as a "public servant" for the purposes of the Hong Kong Basic Law. The term public servant is not defined in the Hong Kong Basic Law, and Ghai (1999) notes "there is nothing which explicitly requires a principal official to be a public servant". 82 However, although not explicit, there are provisions in the Hong Kong Basic Law which are indicative of such a requirement ${ }^{83}$ As such, it would appear unsafe for serving legislators to be appointed as principal officials, unless and until Article 79(4) is amended or interpreted to make its ambit clearer. ${ }^{84}$

No such constitutional obstacles stand in the way of Ghai's first option, that of appointing to Exco legislators representing the largest political groupings in Excosomething which has already been attempted on a limited scale. Indeed the appointment of at least some legislators to Exco is specifically envisaged under Article 55(1) of the Hong Kong Basic Law, which refers to members of the Executive Council being chosen "from among the principal officials of the executive authorities, members of the Legislative Council and public figures".

Cross-membership between the Executive and Legislative Councils has a long history in Hong Kong, with legislators dominating the unofficial (or non-government) membership of Exco for more than three decades during the colonial era. Throughout most of the period from 1946, when such cross-membership began, until it ended in 1992, legislators constituted between half and three quarters of such unofficial members. ${ }^{85}$ Tai (2011) describes it as "a bridge between the Executive and Legco" 86

\footnotetext{
${ }^{80}$ I.e. the Commissioners of the Police, Independent Commission Against Corruption and Customs and Excise, as well as the Directors of Immigration and Audit. These five posts are already excluded from the practice of appointments on fixed-term contracts tied to the term of office of the Chief Executive which applies to other principal official positions under the Principal Officials Accountability System. ${ }^{81}$ The Secretary for Civil Service is currently appointed the ranks of civil servants while the Secretary for Justice is under a quasi-judicial duty, under Article 63 of the Hong Kong Basic Law, to "control criminal prosecutions, free from any interference".

${ }^{82}$ Ghai, Hong Kong's New Constitutional Order (see note 29) at page 295.

${ }^{83}$ Specifically Article 101(1), which seems to refer to those holding principal official posts as public servants. See further Constitutional Affairs Bureau, System of Accountability of Principal Officials (13 December 2001) at http://www.legco.gov.hk/yr01-02/english/panels/ca/papers/ca1217cb2-693-1e.pdf (last accessed on 29 August 2014).

${ }^{84}$ On this point, see further Richard Cullen, "Executive Government Reform in Hong Kong" (2003) 11 Asia Pacific Law Review 57, 73 and Richard Cullen, Xiaonan Yang and Christine Loh, "Executive Government" in Chan and Lim (eds.), Law of the Hong Kong Constitution (see note 1) at page 257. ${ }^{85}$ The only exception was between 1966-78, when the proportion slipped to $25 \%$. Benny Tai, "The Development of Constitutionalism in Hong Kong" in Raymond Wacks (ed.), The New Legal Order in Hong Kong (Hong Kong: Hong Kong University Press, 1999) at page 60.
} 
which played a significant role in averting conflict between the executive and legislature during much of Hong Kong's colonial era. Controversial government proposals were sometimes shelved when legislators sitting in Exco warned that they would likely face a hostile response from their colleagues in Legco. ${ }^{87}$ Miners (1991) attributes the rarity with which the legislature rejected government bills during the colonial era to their prior vetting by Exco. ${ }^{88}$

It is an irony of Hong Kong's constitutional development that this crossmembership should have been ended at precisely the moment when it became potentially most important, while Hong Kong was in the final stages of the transition to a fully-elected Legco where the executive would, almost inevitably, face more difficulty securing support for its policies. It was Chris Patten who broke the decadeslong cross-membership between the two councils, in his first policy address after assuming the post of last colonial Governor in $1992 .{ }^{89}$ Patten did this for essentially short-term political reasons, because continuing such cross-membership would have inevitably led to the appointment of some pro-democracy legislators to Exco, a move which would have brought a furious response from China. ${ }^{90}$ Indeed he dropped a strong hint that ending cross-membership was initially only intended as a temporary measure, announcing a separation the membership of the two councils "for the time being". 91

Patten's 1992 policy address recognised the need to build an alternative bridge between the executive and Legco to replace the one he was demolishing through the abolition of cross-membership, proposing in its place the creation of a GovernmentLegCo Committee with "the vital task of creating an effective working relationship between this Council and the Administration". ${ }^{92}$ This interesting proposal, which might usefully be revisited today, proposed the establishment of a committee chaired by either the Governor, Chief Secretary or Financial Secretary, depending on the subject matter under discussion, which would meet regularly with a representative group of legislators to discuss how the Government's legislative and financial programmes could be conducted more efficiently. ${ }^{93}$

But the Government-LegCo Committee collapsed even before it came into existence, amid bickering among legislators about its composition. And Patten's proposed short-term separation of the two councils subsequently turned into a prolonged long-distance relationship. As a result, Scott (2000) concluded that Patten's

\footnotetext{
${ }^{86}$ Benny Tai, "The Chief Executive" in Chan and Lim, Law of the Hong Kong Constitution (see note 1) at page 202.

${ }^{87}$ See the examples cited in Norman Miners, The Government and Politics of Hong Kong (Hong Kong: Oxford University Press, $5^{\text {th }}$ edition, 1991) at page 77.

${ }^{88}$ Ibid.

${ }^{89}$ Christopher Patten, “Our Next Five Years: The Agenda for Hong Kong”, Policy Address, 7 Oct 1992, at para. 116.

${ }^{90}$ Patten subsequently noted [in East and West: China, Power, and the Future of Asia (New York: Times Books, 1998)] that it would have been quite impossible to have some legislators on my Executive Council but to exclude any democrats ... Separation therefore seemed sensible".

${ }^{91}$ Patten, "Our Next Five Years" (see note 89) at para. 116.

${ }^{92}$ Ibid. at para. 123.

${ }^{93}$ Ibid.
} 
1992 "decision contributed considerably to the subsequent disarticulated system" and "the continuing disjunction between the work of the two councils". 94

Although the total separation of the membership of the two councils was reversed after the establishment of the HKSAR, legislators have never yet returned to Exco in anything like the same numbers, or with the same dominance, as was the case during the many decades when they served as a "bridge" between the two bodies during the colonial era. No Executive Council since 1 July 1997 has ever had more than three legislators among its ranks and, given the growth in the size of Exco, these legislators constitute a much smaller proportion of its total membership-currently just over $20 \%$ of the unofficial members of Exco. ${ }^{95}$

It is difficult to believe efforts to build bridge with Legco through overlapping membership are being pursued with much seriousness when a new Chief Executive initially appoints as many members of his campaign team to Exco as legislators. ${ }^{96}$ Or that such appointments form part of a serious strategy to secure support from the larger political grouping in Legco when Regina Ip is given a seat on Exco-whose New People's Party has only two seats in Legco — while the generally proestablishment Liberal Party is ignored, despite having four seats, or twice as large a presence in Legco.

Any serious strategy of using such appointments to build bridges with the legislature would have to include offering places on Exco to all political parties with a significant presence in Legco. That would mean reaching out to mainstream groups within the pan-democratic camp, such as the Democratic Party and the Civic Party. Since such groups would be unlikely to accept the collective responsibility rule as it has been traditionally practised in Exco, that rule would need to be reviewed. However if a minimum threshold of say five seats in Legco was required before any party was offered a seat on Exco, that would exclude more radical pan-democratic groups whose presence would be presumably considered beyond the pale.

It would, of course, be a mistake to automatically assume that simply because a strategy of appointing legislators as the dominant unofficial grouping in Exco contributed to a smoother executive-legislative relationship many decades ago, at a time when the members of the legislature were appointed by the executive, the same strategy would necessarily have the same effect in today's very different environment. Nonetheless there would appear to be little harm in trying and of all the options for trying to bridge the executive-legislative divide considered in this article it would appear to be the most realistic in the short-term.

Even a future Chief Executive elected by universal suffrage would still need to secure support for government policies from legislators whose political fortunes are not automatically tied to the Chief Executive, and bringing more of them into Exco would be one way of seeking to achieve this.

\footnotetext{
${ }^{94}$ Scott, “The Disarticulation of Hong Kong's Post-Handover Political System" (see note 45) at page 40 .

${ }^{95}$ As of September 2014, legislators constituted 3 out of the 14 unofficial members. See http://www.ceo.gov.hk/exco/eng/membership.html. (last accessed on 5 September 2014).

${ }^{96}$ Two members of CY Leung's campaign team, Fanny Law and Barry Cheung, were appointed to Exco when he took office in July 2012, along with two legislators, Starry Lee and Jeffrey Lam. However the balance subsequently changed when a third legislator, Regina Ip, was appointed in October 2012 while Cheung subsequently resigned in May 2013.
} 


\section{Conclusion}

It should be stressed once again that it is not the intention of this paper to diminish the role that the introduction of universal suffrage for the election of the Chief Executive would play in addressing the current problems with Hong Kong's political system. But, for all its importance, universal suffrage would be unlikely to solve those problems alone, unless it is part of a package of reforms that also address the structural problems caused by the near total separation of the membership of the executive and legislature. While it would be far preferable for those reforms to be implemented together as a package, the fact that it may ultimately prove impossible to proceed with any one part of that package - even a part as important as universal suffrage - should not necessarily preclude efforts to move forward on other fronts.

However it would be wise to be realistic about the limits of what can be achieved, even if such reforms can be implemented in their entirety, universal suffrage and all. Separation of powers, especially in the form which it is practised in Hong Kong, is not a doctrine which lends itself naturally to a smooth working relationship between the executive and legislature. Brandeis J. put the point most aptly in Myers $v$ United States (1926), pointing out that the doctrine was adopted in the US Constitution, "not to promote efficiency but to preclude the exercise of arbitrary power. The purpose was not to avoid friction, but, by means of the inevitable friction incident to the distribution of the governmental powers among three departments, to save the people from autocracy". 97

Some degree of friction is even more inevitable in the special circumstances in which Hong Kong finds itself, with one country two systems imposing certain constraints on what type of political system Hong Kong can adopt. As Chen (2007) notes: "To keep this strange political animal alive, Hong Kong may have to pay the price of having a system of governance that is less than healthy and effective". ${ }^{98}$ Nor is a certain degree of friction necessarily undesirable. Few would wish to see a situation where the legislature agreed with the executive on everything, and the checks and balances between the two institutions evaporated. As Ma (2002) notes: "Executive-legislative relations are most 'harmonious' in places where the executive can largely control the legislature, as in one-party dictatorships and oligarchies in Africa or Middle East." 99

But, while perfect harmony might be undesirable, most would agree that the situation in Hong Kong has swung too far in the opposite direction towards continual executive-legislative conflict at present. While being realistic about the limits of any reform, Hong Kong can do better-and addressing the issues raised by our system of separation of powers deserve to be considered in tandem with the introduction of universal suffrage.

\footnotetext{
${ }^{97}$ (1926) 272 U.S. 52, 293.

${ }^{98}$ Chen, "The Basic Law and the Development of the Political System in Hong Kong" (see note 53) at page 40 .

${ }^{99}$ Ma Ngok, "Executive-Legislative Relations: Assessing Legislative Influence in an ExecutiveDominant System" (see note 42) at pages 354-355.
} 